Cahiers $d u$ MONDE RUSSE

\section{Cahiers du monde russe}

Russie - Empire russe - Union soviétique et États indépendants

$52 / 4 \mid 2011$

Varia

\title{
Svetlana Malyševa, Prazdnyj den', dosužij večer
}

\section{Louise McReynolds}

\section{OpenEdition \\ Journals}

\section{Electronic version}

URL: http://journals.openedition.org/monderusse/7610

DOI: $10.4000 /$ monderusse. 7610

ISSN: $1777-5388$

\section{Publisher}

Éditions de l'EHESS

\section{Printed version}

Date of publication: 20 December 2011

Number of pages: $727-728$

ISBN: 978-2-7132-2353-2

ISSN: $1252-6576$

\section{Electronic reference}

Louise McReynolds, "Svetlana Malyševa, Prazdnyj den', dosužij večer », Cahiers du monde russe [Online], 52/4 | 2011, Online since 03 December 2012, Connection on 25 September 2020. URL : http:// journals.openedition.org/monderusse/7610; DOI : https://doi.org/10.4000/monderusse.7610

This text was automatically generated on 25 September 2020 


\title{
Svetlana Malyševa, Prazdnyj den', dosužij večer
}

\author{
Louise McReynolds
}

\section{REFERENCES}

Svetlana MALYŠEVA, Prazdnyj den', dosužij večer: kul'tura dosuga rossijskogo provincial'nogo goroda vtoroj poloviny XIX-nachala XX veka [Festive Days, Leisure Evenings: The Culture of Leisure in a Provincial Russian City in the Second Half of the Nineteenth-Beginning of the Twentieth Centuries]. M. : Academia, 2011, 192 p.

1 How does one even translate the title of this book? As Svetlana Malysheva, a professor of history at Kazan' University, makes clear in her introduction, "leisure" remains as contested a notion as when sociologists began connecting it with political and social change early in the nineteenth century. It's about time away from work, and time organized by Church and State. Building upon her past work on both leisure in the 1920s and daily life in Kazan', Malysheva brings a valuable new dimension to our understanding of provincial life before the revolution. Like Catherine Evtukhov's recent book on Nizhnyi Novgorod, Prazdnyi den', dosuzhij vecher takes readers along the Volga, as it also provides valuable new insights into interethnic, Russian and Tatar, relations at very fundamental levels of social engagements. This turn to provincial cities is welcome indeed because these urban populations did not simply mimic on a smaller scale those in the two capitals, even when the official calendar of state and religious holidays was distributed empire-wide.

2 Malysheva, more concerned with the structure than the contents of leisure, divides her study into four chapters: leisure as a space for intercultural communications; the issue of "time," according to both clock and calendar; the place of leisure in the transformation of urban spaces; and the "forms and structure" of provincial leisure, with an emphasis here on official efforts to, if not outright control activities, at least to manage them through the granting and withholding of permits for activities in public. 
Theoretically informed, Malysheva uses Mikhail Bakhtin's notion of "chronotope" to bring readers' attention to the temporal and spatial changes inflected by leisure, not restricted to a single definition. The book is nicely illustrated, permitting readers to witness Kazanites at play.

The thread that brings the chapters together is modernization and the evolution of pluralism in entertainment, but not homogenization. Malysheva's most informative contribution is to put Russians and Tatars together in social situations, Russian boys chasing Tatar girls, who would themselves often be subjected to arranged marriages, which enhanced the appeal of the Russian flirts. Divisions according to education were not necessarily demarcated by the highbrow/lowbrow dichotomy. University students also enjoyed significantly more leeway out on the streets than gymnasium students, and although Vera Figner complained bitterly about regimentation, some of her colleagues demonstrated the familiar ingenuity of schoolgirls everywhere when they disguised themselves as maids to get out at night. And for all of the enmity between cops and college boys, the police chief knew enough to keep his men from trying to quiet down the carousing young men celebrating their university's holiday. The long village tradition of "the wall," fisticuffs between bored young men, would be played out between Tatars and Russians on the winter's ice. And nor is every Moslem pious; Orenburg merchant Kh. Khusainov paid 800 rubles to be the only guest one night at a Kazan' brothel.

4 In many respects, Malysheva has written an urban history, because she traces how leisure activities contributed to the transformation of urban spaces, when, for example, streetlights increased public safety, making it possible for people to go out more, rather than staying in and entertaining at home. The weather itself divided winter spaces in the center from summer parks on the periphery. Increased industrialization complemented brought more money into circulation, and workers as well as the betterheeled urban groups would combine resources to rent spaces for parties. The entertainment paradigm that Malysheva draws is one of overlapping circles; sexes, ethnicities, and social estates are themselves diversified, which allows for democratic interactions. When mass-oriented Tatar-language theaters began sprouting at the turn of the century, devoutly Moslem leaders protested while their children took in the performances.

5 Fully versed in German and English-language studies of leisure, Malysheva adds to the historiographical literature by bringing so many interethnic angles to the table. Her work on the disputes between which days to close shops, Fridays (Moslem) or Sundays (Christian) reminds of the complexity of deciding when to rest and when to work. This particularly valuable study, though focused on multiethnic Kazan', reminds that the Russian provinces enjoyed a life of their own. 